\title{
COMPARATIVE STUDY OF ONLINE CUSTOMER SATISFACTION BETWEEN CERTIFIED AND NON- CERTIFIED TOURISM SMES
}

\author{
Triin Veideman
}

https://doi.org/10.20867/tosee.05.44

\begin{abstract}
Purpose - The number of tourism choices is growing exponentially and quality is one of the most important sources of competitive advantage for a destination, playing a critical role in attracting both new and repeat arrivals. The purpose of this study is to explore the relationship between implemented quality certification and online customer satisfaction. Destination Management Organizations (DMOs) initiate quality certifications to regulate the market and help customers make their purchase decisions. However, it is still unclear if there is a link between the certificates awarded to an enterprise and the satisfaction of its customers. Small and medium tourism enterprises (SMTEs) are used as a case study, applying distinctive focus compared to prior studies concentrating on large hotels.

Methodology - An empirical analysis is carried out comparing 66 quality certified SMTEs with 169 non-certified SMTEs using secondary data derived from various online platforms.

Findings - Quality certification is an effective tool to achieve customer satisfaction as the findings indicate that quality certified SMTEs receive higher online scores and increase the number of online reviews after implementing the certification.

Contribution - This study contributes to the limited literature on quality management in tourism sector investigating the connection between quality certification and online customer satisfaction. The results from this research are presentable as guidelines for destination managers to advance quality certification offered for SMTEs. In a market situation where digital technology is rapidly changing the business environment for tourism sector.

Keywords Destination Management, Quality Certification, Customer Satisfaction, Online Reviews

\section{INTRODUCTION}

The contemporary tourism has undergone rapid growth leading to an increase in international competition between tourism destinations (Namhyun and Wicks 2010). It is becoming more difficult for the customers to make decisions as the number of choices is growing exponentially. At the same time, destinations are exploring opportunities to attract new and retain existing customers to remain competitive. Fundamental for creating a positive post-purchase behavior is to achieve higher customer satisfaction level (Yoon and Uysal 2005).
\end{abstract}


ToSEE - Tourism in Southern and Eastern Europe, Vol. 5, pp. 739-756, 2019

T. Veideman: COMPARATIVE STUDY OF ONLINE CUSTOMER SATISFACTION BETWEEN ...

Common strategy for destination management organizations DMOs to assure customer satisfaction and sustain the position of a competitive tourism destination is via quality certification. SMTEs implementing those schemes are expected to provide quality service to meet and exceed the expectations of more mobile, more demanding and more educated (Dukić and Kijevčanin 2012) customers. Due to the widespread access to digital technology, customers share their experiences via online ratings and reviews. Prospective travelers use that online content as one of the main sources of information for their travel decisions. However, it has remained unclear if there is a link between the quality certification implemented and the satisfaction of customers.

There is a growing demand for increased research in the area that merges the concepts of quality management and customer satisfaction (Kobylanski et.al 2011). Despite several separate studies in tourism focusing on online reviews (Ye et. al 2008, Browning et. al 2013, Sparks et. al 2013, Pourfakhimi, 2014, Phillips 2015, Komšić and Dorčić 2016, Lui et. al 2018, Niu and Fan 2018) and on the effect of quality management on customer satisfaction (Vajčnerová et. al 2014, Reyner et. al 2017), there is no empirical research which would explore the relationship between quality certification and online customer satisfaction. There is a particular research gap in studies based on the evaluations or ratings of customers for certified enterprises in comparison with noncertified enterprises (Heras-Saizarbitoria 2015). This paper aims to eliminate this gap proposing the following research question: Do SMTEs with quality certification perform better in terms of online customer satisfaction than non-quality certified SMTEs?

In order to answer to this question, these two hypotheses $(\mathrm{H})$ will be the focal point of this study:

H1: quality certified SMTEs have more online ratings than non-certified SMTEs.

$\mathrm{H} 2$ : quality certified SMTEs receive higher online ratings than non-certified SMTEs.

This comparative study on customer satisfaction between certified and non-certified SMTEs contributes to limited literature on quality management in tourism sector investigating the effectiveness of certification scheme as a tool to achieve online customer satisfaction. With a different focus compared to prior studies, due to the predominance of small and medium enterprises in the tourism sector. Data from this study comes from Estonia. SMTEs in Estonia represent $99.2 \%$ of the total tourism businesses, the largest percentage of tourism establishments in the country.

The structure of this paper is as follows. The next section presents the theoretical framework on the relationship between quality certification and online customer satisfaction. The further section describes the methodology adopted to test these relationships in Estonian SMTEs. The results of the quantitative analysis are then summarized. The study concludes with a summary discussion, the contribution of the study and limitations together with implications for further research. 
ToSEE - Tourism in Southern and Eastern Europe, Vol. 5, pp. 739-756, 2019

T. Veideman: COMPARATIVE STUDY OF ONLINE CUSTOMER SATISFACTION BETWEEN ...

\section{LITERATURE REVIEW AND RESEARCH HYPOTHESES}

In tourism, customers are the core of the business requiring new products and services that are more reliable. Such environment directs SMTEs to meet or exceed the expectations of those increasingly demanding customers. High level of customer satisfaction is the main tool for creating a long-term loyalty, business stability, growth and development of the company (Mehra and Ranganathan 2008, Đukić and Kijevčanin 2012). The discrepancy between customers expected product and delivered product is a basic measure for quality (Piskar 2007). Even the most widely accepted definition of quality places customers and the fulfillment of their requirements at the center of a business (Lleshi and Lani 2017). High level of quality and customer satisfaction cannot be separated (Ooi et.al 2011) as customers are the main financial contributors and their satisfaction indicates whether SMTEs are offering the right product in the right way.

In order to enhance customer satisfaction, an individual tourism organization should adopt the same understanding of quality as its customers (Augustyn 1998). This is a difficult task, since the end users of tourism product are heterogeneous (Holjevac 1996) and the perception of what is a good product may vary with the needs and attitude of a customer (Weckenmann et.al 2015). Business travelers usually value quick service, fast internet connection and good transport connection, whereas family with three children might expect special attention provided for their children, kids channels on hotel's TV and service options for childcare. Therefore, the most profound way to achieve customer satisfaction is to find out what does quality mean to the specific customer segment or an individual customer, what keeps them satisfied or causes dissatisfaction.

Measuring customer satisfaction is a matter of sustainability, continuously listening to customers and monitoring the company's efforts in the eyes of the final customers (Eklof and Westlund 1998). This can be a challenging and delicate issue for SMTEs due to the predominance of subjectivity in the evaluation (Butnaru and Miller 2012). In addition, SMTEs often lack time or other resources to explore the causes of customer satisfaction or dissatisfaction. A study by Fourie (2015) indicated that although the majority of SME owners understand the importance of collecting customer feedback, they do not necessarily have a formal measurement in place, but rather collect customer satisfaction feedback verbally on an ongoing basis. The shortage of knowledge of the level of satisfaction or dissatisfaction of customers is a cause of failure of many companies (Dukić and Kijevčanin 2012). In order to prevent the failure SMTEs need to gather customer feedback systematically, analyze it to verify the areas for improvement and act upon those results by conducting necessary changes.

One of the most widespread ways of dealing with challenges of this nature involves the institution of a certified quality system (Alonso-Almeida et al. 2012), majority of them based on total quality management (TQM) approach. A meta-analytic research conducted by Mehra and Ranganathan (2008) propose a working definition for TQM as follows: "TQM is a management strategy that, with sound design and successful implementation, can be adopted to enhance customer satisfaction through a concerted focus on customers. In spite of its complicated nature, TQM of the tourism product is possible and very necessary" (Holjevac 1996). Prevalent tourism quality certifications 
ToSEE - Tourism in Southern and Eastern Europe, Vol. 5, pp. 739-756, 2019

T. Veideman: COMPARATIVE STUDY OF ONLINE CUSTOMER SATISFACTION BETWEEN ...

incorporate six dimensions of organizational practices, namely leadership, strategic and planning, information and analysis, human resource focus, process management and customer focus in their widely acknowledged and accepted quality management framework. Among categories to evaluate the performance, certification scheme emphasize the importance of customer feedback measurement. Although, according to Augustyn (1998), great deal of SMTEs that participate in regional schemes aim at obtaining a certificate to magnify their promotional strengths rather than to increase customer satisfaction. Nevertheless, customer satisfaction is becoming one of the important judging factors in quality certifications (Mehra and Ranganathan 2008). Applicants are provided with tools to collect, measure and analyze customer feedback in order to meet customer expectations. The dimensions of customer focus, information and analysis are strongly linked to customer satisfaction and service quality (Ooi et.al 2011). This framework, with a focus on customer satisfaction, has been selected to test the propositions of this research.

Recent years have witnessed an explosion in user-generated reviews with customers increasingly expressing opinions on recent purchases as well as seeking opinions of others prior to their purchases (Mauri and Minazzi 2013, Anderson and BlombergNygard 2016). The percentage of customers consulting reviews at TripAdvisor prior to booking a hotel room has steadily increased over time, as has the number of reviews they are reading prior to making their hotel choice (Anderson 2012). In addition to hotel and other accommodation facilities, customers are contributing their time and effort to browse through ratings and comments for attractions, nature parks, food and beverage establishments etc. Online content, especially produced by users on social media platforms, is one of the main sources of information for prospective customers. Considering customer habits to consume online and social media, tourism service providers need to manage their online reputation with the utmost care.

Online customer feedback as compared to traditional forms of feedback is even more visible and accessible and creates the foundation of SMTE's online reputation. It is challenging for an SMTE to monitor and manage traditional word of mouth (WOM) because traditional WOM is usually exchanged in private conversations and is ephemeral (Ishida et.al 2016). Whereas, online reputation as a communication activity is carried out by customers in an external environment outside the direct control of a company (Rodríguez-Díaz et. al 2018). Observing messages posted on review sites may help to monitor different kinds of images in a timely and cost effective way (Ishida et.al 2016). Effectively managing ratings and reviews influences not only the satisfaction of customers leaving the comments, but also the perception of potential future customers. Certification scheme as a tool to improve the efficiency of a company and reduce the amount of incidents and complaints (Tari et.al 2013) should also contribute to improving company`s online reputation. In fact, Rodríguez-Díaz et. al (2018) are proposing that online customer valuations are in some ways replacing the traditional model for measuring service quality. Certification scheme should comprehend the way online customer feedback influences customers` decisions and expectations through providing specific criteria and tools that consider the synergy among social media and the development of mobile technologies. 
ToSEE - Tourism in Southern and Eastern Europe, Vol. 5, pp. 739-756, 2019

T. Veideman: COMPARATIVE STUDY OF ONLINE CUSTOMER SATISFACTION BETWEEN ...

Currently, there is a controversial situation for the organization, because a certificate procedure is applied to measure customer results, but the customers themselves are writing about and evaluating critical aspects such as the constructs of service quality, perceived value, and satisfaction online (Rodríguez-Díaz 2018 gap analysis). Adapting to this digital technology driven market change means that SMTEs should encourage their customers to give online comments after the visit as they are the main source of information for prospective new customers. SMTEs who have implemented quality certification scheme have acquired knowhow how to encourage their customers to give feedback after the visit. Preferably online, as this feedback is more valuable being the main source of information for prospective new customers. Further, those reviews add search engine optimization value to reviewed SMTE and complement the content gaps that may exist on the business website increasing the overall visibility and ranking in the Google. Displayed on the first page in the search results when customers are looking for an accommodation to spend the night gives a valuable competitive advantage for a SMTE and increases the likelihood of confirmed booking. Considering the rapid growth of ICT communications, this feedback is more valuable when published online. Based on this literature, this study posits the following hypothesis:

H1: Q certified SMTEs have more online ratings than non-certified SMTEs.

The previous research findings confirm the link between quality system and customer satisfaction. The research conducted by Ooi and others (2011) showed that total quality management practices are significantly and positively connected to customer satisfaction and service quality of the small service business firms. Another research results proved that with some factors there is a link between the quality standard ISO 9000 and customer satisfaction (Piskar, 2007). Mehra and Ranganathan (2008) found that implementing TQM programs in an organization directly and positively impacts customer satisfaction. Thus, organizations that successfully implement TQM will benefit from increased customer satisfaction. These studies provide justification to believe that implementation of $\mathrm{Q}$ certification can result in increased customer satisfaction. Conformably, service quality evaluation and customer satisfaction remain key factors stimulating positive online customer reviews (Mauri and Minazzi 2013). Hence, this study will propose a direct positive relationship between quality management and customer satisfaction and posit second hypothesis as follows:

H2: Q certified SMTEs receive higher online ratings than non-certified SMTEs.

\section{METHODOLOGY}

The objective of this study is to explore the relationship between quality management and customer satisfaction based on customer online reviews for certified SMTEs in comparison with non-certified SMTEs. Although there are many books and articles discussing tourism certification in general, there are few peer-reviewed articles analyzing specific programs in detail (Tepelus and Cordoba 2005). The most widely studied quality management program in tourism is ISO certification suitable for large enterprises. This leaves national quality certification schemes tailored for SMTEs, inherent in various countries, lack of comprehensive attention in previous research. 
ToSEE - Tourism in Southern and Eastern Europe, Vol. 5, pp. 739-756, 2019

T. Veideman: COMPARATIVE STUDY OF ONLINE CUSTOMER SATISFACTION BETWEEN ...

Estonian rural tourism sector is used as a case study for three reasons. First, due to the predominance of SMTEs in Estonian rural tourism makes it a fairly homogenous subsector of tourism. Secondly, Second, in order to gain and maintain the position as a competitive tourism destination, Estonian Tourist Board (ETB) in co-operation with Estonian Rural Tourism Association (ERTA) have launched national eco certification label called EHE (Genuine and Interesting Estonia). Third, the ease of access to comprehensive online review data of Estonian rural tourism SMEs published by customers on online travel agencies (OTAs). Instead of gathering inconspicuous information from countless OTAs, the compact data for analysis is derived from platform named ReviewPro. Listed circumstances offer appropriate foundation to analyze the effectiveness of certification scheme as a tool to achieve customer satisfaction.

The non-profit organization ERTA was set up in 2000 with the objective to represent the common interests of rural tourism service providers in order to support the development of countryside tourism in Estonia. ERTA has the right to award the EHE eco-label according to the confirmed rules. The label is given to the tourism enterprise for three years. After the expiration of the term, the enterprise needs to renew the label.

National eco-certification scheme, launched in 2003 and revised in 2015, considers all the minimum criteria of quality assurance also referenced by the European Hospitality Quality Scheme (EHQ). EHE eco-certification is inherent with the current study, emphasizing principals that specifically support enhancing customer satisfaction:

- Guest oriented processes including maintenance, safety and cleanliness,

- Systematic complaint management covering the complaints (also via the Internet),

- Revision of action plan taking into account guest surveys (online and/or offline reviews),

- Provision of correct information about services in at least one relevant foreign, language if appropriate to location and business concept,

- Information on a choice of local services and products,

- Limited duration of quality assessment.

Those criteria provide ground for an assumption that SMTEs accredited with the ecocertification are meeting their customer expectations and have achieved customer satisfaction, which is reflected through online reviews.

In 2018 there were 66 EHE eco-certified SMTEs in Estonia, who all are included in this study. The sampling frame for non-certified SMTEs identified in the data collection process contained SMEs with a valid membership of ERTA. The non-certified SMTEs where selected via purposive sampling to ensure that the results provided are robust and avoid potential bias (Cochran 2007). Chosen sampling criteria assured non-certified SMTEs having similar characteristics as certified SMTEs in terms of size, fields of activity and location. The number of non-certified SMTEs included in this study is 169.

The data collection for empirical study is based on secondary data obtained from a service provider named ReviewPro. Their Global Review Index (GRI) is an aggregate online reputation score based on scores given by customers on major online review sites, social media platforms and online travel agencies (OTAs). The GRI is calculated for an 
ToSEE - Tourism in Southern and Eastern Europe, Vol. 5, pp. 739-756, 2019

T. Veideman: COMPARATIVE STUDY OF ONLINE CUSTOMER SATISFACTION BETWEEN ...

individual enterprise by analyzing quantitative scores on these sites, using a proprietary algorithm (Anderson 2012).

Online review data is used to improve the trustworthiness of information on customer satisfaction (Zhou et al. 2014). Unlike traditional studies, which are based on information gathered from inside the organization, often provide a basis for certain biases. These biases are particularly related to the assessment of service quality by managers themselves (self-reporting bias) and the tendency to prevaricate over undesirable aspects that could undermine the image or social legitimacy of the organization (social desirability bias) (Heras-Saizarbitoria 2015). Reviews and ratings posted by customers enable to reflect the real time situation with the most accurate assessment on actual satisfaction.

The period analyzed was one year from $1^{\text {st }}$ of October 2017 until $30^{\text {th }}$ of September 2018. ReviewPro analyses the data in accordance with the previous period, accordingly from $1^{\text {st }}$ of October 2016 until $30^{\text {th }}$ of September 2017. R studio was used to execute the necessary analysis (RStudio 2019).

\section{DATA ANALYSIS}

This paragraph begins with presenting some introductory descriptive statistics of the sample. Table 1 shows the total sample of 235 SMTEs with similar characteristics in terms of size, fields of activity and location, from which 66 are certified and 169 are noncertified. From certified SMTEs, 21 (31.8\%) have received online reviews and ratings from customers to include their GRI into this study. For non-certified SMTEs, the same indicator is higher, allowing to conduct the analysis on 87 (51.5\%) SMTEs.

Table 1: Descriptive statistics of the sample

\begin{tabular}{|l|c|c|c|}
\hline & $\begin{array}{c}\text { No of SMTEs used in } \\
\text { the study }\end{array}$ & $\begin{array}{c}\text { No of SMTEs with } \\
\text { online score }\end{array}$ & $\begin{array}{c}\text { The \% of SMTEs with } \\
\text { online scores }\end{array}$ \\
\hline Certified & 66 & 21 & $31.8 \%$ \\
\hline Non-certified & 169 & 87 & $51.5 \%$ \\
\hline TOTAL & 235 & 108 & \\
\hline
\end{tabular}

Source: The author

Figure 1 escribes the distribution of online reviews given by customers. Certified SMTEs (1) have overall higher online review scores and the scores are more evenly allocated in comparison with non-certified SMTEs (0). 
ToSEE - Tourism in Southern and Eastern Europe, Vol. 5, pp. 739-756, 2019

T. Veideman: COMPARATIVE STUDY OF ONLINE CUSTOMER SATISFACTION BETWEEN ...

Figure 1: Distribution of online reviews

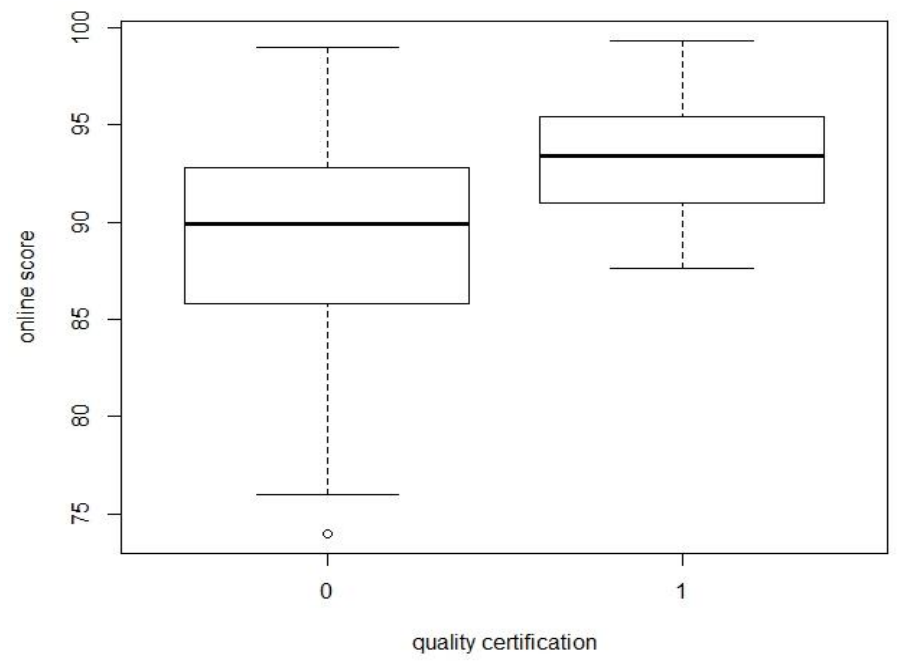

Source: The author

Figure 2 illustrates the dispersion of SMTEs according to the amount of reviews and the scores given. Certified SMTEs (marked as red triangles) are more homogenously allocated and they locate in the left corner of the matrix, which indicates that they have higher online scores but not as much online reviews. The same figure explicitly shows how non-certified SMTEs (marked as green squares) allocation is more inconsistent in terms of both indicators. The amount of reviews in the $\mathrm{x}$-axis vary in a larger scale and review scores are distributed from top to the bottom of the y-axis.

Figure 2: Dispersion of certified and non-certified SMTEs according to the amount of reviews and the scores given

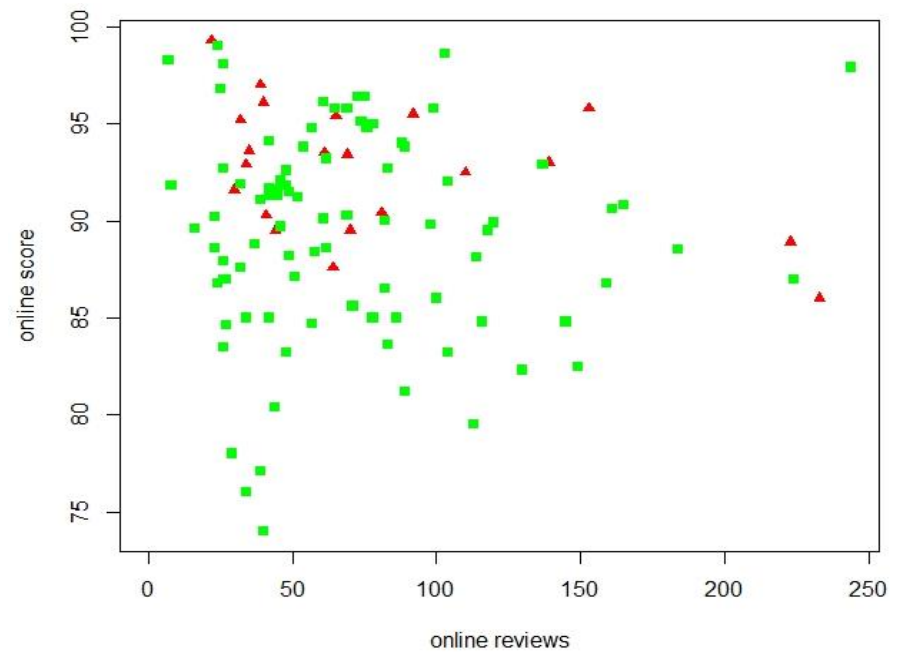

Source: The author 
ToSEE - Tourism in Southern and Eastern Europe, Vol. 5, pp. 739-756, 2019

T. Veideman: COMPARATIVE STUDY OF ONLINE CUSTOMER SATISFACTION BETWEEN

To identify the variation in the amount of reviews and difference in rating scores between certified and non-certified SMEs, an independent-samples t-test was performed and the results are reported in Table 2.

Table 2: The results of the T-test

\begin{tabular}{|l|c|c|c|c|c|}
\hline & $\begin{array}{c}\text { Certifi- } \\
\text { cation }\end{array}$ & Mean & Std. Deviation & T-test & $\begin{array}{c}\text { T-test sign. } \\
\text { (p-value) }\end{array}$ \\
\hline $\begin{array}{l}\text { Number of } \\
\text { reviews }\end{array}$ & 1 & 27.9697 & 49.23413 & 1.676 & 0.0965 \\
\hline & 0 & 39.76331 & 46.48505 & & \\
\hline Rating scores & 1 & 92.71429 & 3.352504 & -3.627 & 0.0006902 \\
\hline & 0 & 89.33563 & 5.378639 & & \\
\hline
\end{tabular}

Source: The author

According to the results, certified SMTEs have higher mean for review scores than noncertified SMTEs, which indicates that customers are more satisfied with the service provided by certified SMTEs. Then again, the descriptive statistics reveal that the mean for number of reviews is 11.9 points higher for non-certified SMTEs in comparison to certified SMTEs, respectively 39.8 and 27.9. One probable explanation behind this variation could be the essence of certified products. EHE eco-labeled products are more exquisite and target customers with special interest. Operating in a niche segment might result in less extensive customer volumes, which will understandably affect the amount of online reviews.

The T-test indicates no statistically significant difference in means in terms on number of online reviews as the result was 1.676 . The fact that 0 hypotheses cannot be rejected verifies the unnecessity to compare the number of reviews given to certified and noncertified SMTEs.

After conducting the T-test for online review scores with the result -3.627 it is evident that there is statistically significant difference in means and those variables are comparable. Looking at the standard deviation it becomes visible that certified SMTEs have more steady online review scores, whereas non-certified SMTEs have more extensive variation in their scores. This supports the assumption that certified SMTEs are able to provide more evenly stable quality of their services.

Next step was to confirm whether there is a correlation between the number of reviews and scores given (Table 3). Investigating this possibility will help to understand if the explanation behind the reason for certified SMTEs having higher online ratings might be due to the fact that non-certified SMTEs have more reviews. More reviews increase the likelihood of unsatisfied customers expressing their emotions and lowering online score. 
ToSEE - Tourism in Southern and Eastern Europe, Vol. 5, pp. 739-756, 2019

T. Veideman: COMPARATIVE STUDY OF ONLINE CUSTOMER SATISFACTION BETWEEN ...

Table 3: The results of correlation analysis

\begin{tabular}{|c|c|c|c|}
\hline & & Online reviews & Online scores \\
\hline Online reviews & Pearson Correlation & 1 & -0.04755835 \\
\hline & Significance & 0 & 0.625 \\
\hline Online scores & Pearson Correlation & -0.04755835 & 1 \\
\hline & Significance & 0.625 & 0 \\
\hline
\end{tabular}

Source: The author

Table 3 reveals that the amount of reviews is not correlated with the ratings given. The significance is higher than 0.05 , which shows no significant correlation between those two variables. Therefore, Pearson Correlation indicates that there is no reason to suggest that SMTEs who have more reviews receive lower rating scores. This provides ground for an assumption that even though certified SMTEs have less reviews they have higher online scores because their customers perceive better quality for the services provided. Having concluded the correlation, the author applied linear regression analysis to further investigate the relationship between two variables, quality certification and online customer satisfaction. The results of linear regression are displayed in Figure 3.

Figure 3: Numeric results of the linear regression

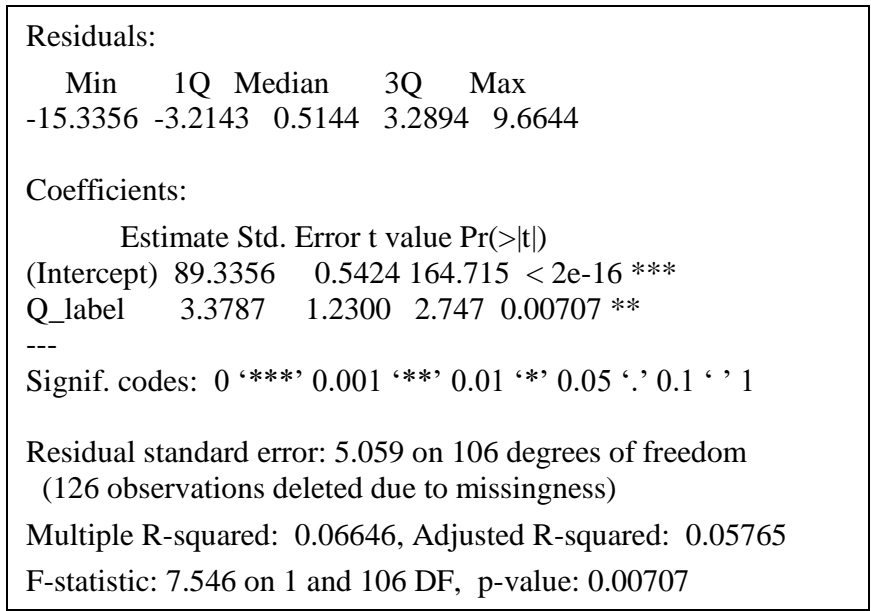

Source: The author

Estimation of the relationship between certification and customer satisfaction indicates that if an SMTE will implement a quality certification, it's online score (GRI) will increase 3.3787 (Figure 4). The T-value is bigger than 2, which means that the prediction model is functioning. As the p-value 0.00707 is smaller than 0.05 the results state that the data is statistically significant. The residual standard error shows that the online score can deviate from the true regression line by 5.059 points. Furthermore, Andersons (2012) research on social media and hotel pricing power revealed that 1-point increase in user review score (on an OTA's 5-point scale) would allow a property to increase price by 11.2 percent and maintain the same purchase probability or market share. Linking the 
ToSEE - Tourism in Southern and Eastern Europe, Vol. 5, pp. 739-756, 2019

T. Veideman: COMPARATIVE STUDY OF ONLINE CUSTOMER SATISFACTION BETWEEN ...

results of his research with the findings of the current study allows to assume that certified SMTEs could increase their prices without losing any customers.

Figure 4: The linear regression model

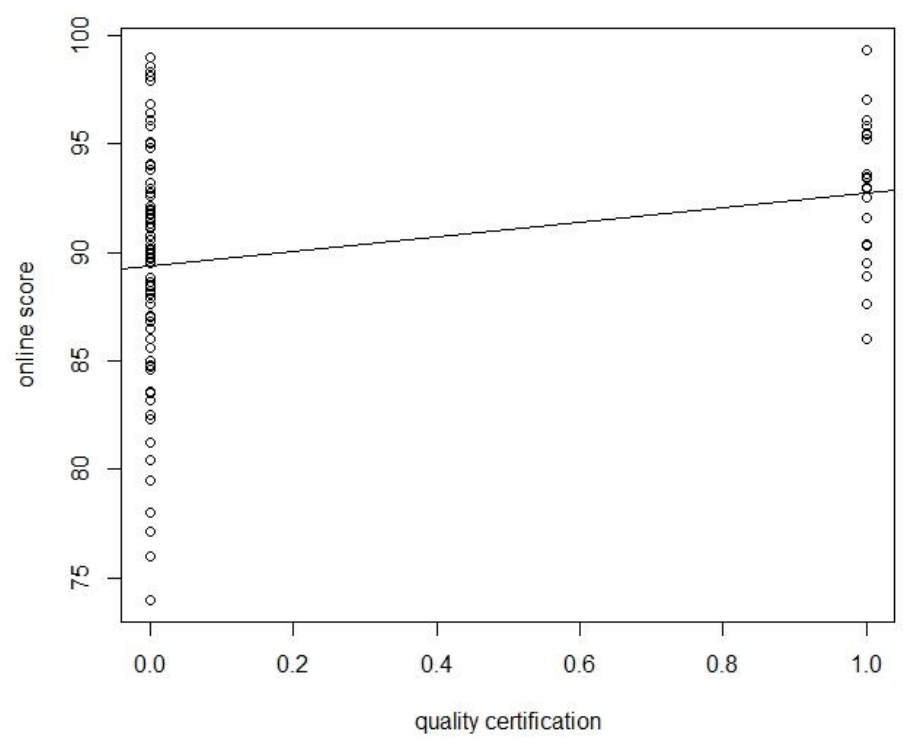

Source: The author

Although the relationship between the implementation of certification and the satisfaction of customers in tourism industry has not been widely studied empirically, there is some research applicable to compare with this one. Heras-Saizarbitoria and others (2015) carried out a statistical analysis similar to this research with a focus on ISO 9001 certification in the context of hotels. Their findings show that although the ISO 9001 certification is essentially aimed at improving internal practices and customer satisfaction, quality certified hotels do not receive a statistically significantly better evaluation or rating from their customers. The authors suggest that the ineffectiveness of the ISO 9001 certification observed in the study may be related to the way the standard is implemented in the hotels studied rather than the foundations of the standard. In comparison to SMTEs, large hotels have more employees to engage in the quality management system. Therefore, internal processes to improve customer satisfaction are more challenging and time consuming. More extensive customer base enhances the demands of various segments and requires superior agility to adapt with customer needs and expectations. This could explain why larger hotels do not benefit from certification in terms of online reputation, whereas the implementation of certification does provide competitive advantage for SMTEs. Due to their smallness, latter are more adaptable and responsive to execute the necessary changes required for certification. 
ToSEE - Tourism in Southern and Eastern Europe, Vol. 5, pp. 739-756, 2019

T. Veideman: COMPARATIVE STUDY OF ONLINE CUSTOMER SATISFACTION BETWEEN

Further exploration included correlation analysis on online reviews and the length of the period in months since the certification had been implemented. Results demonstrate that formerly certified SMTEs have higher scores than SMTEs that have received the certification in a later period (Figure 5).

Figure 5: The results of correlation analysis on online score and certification period

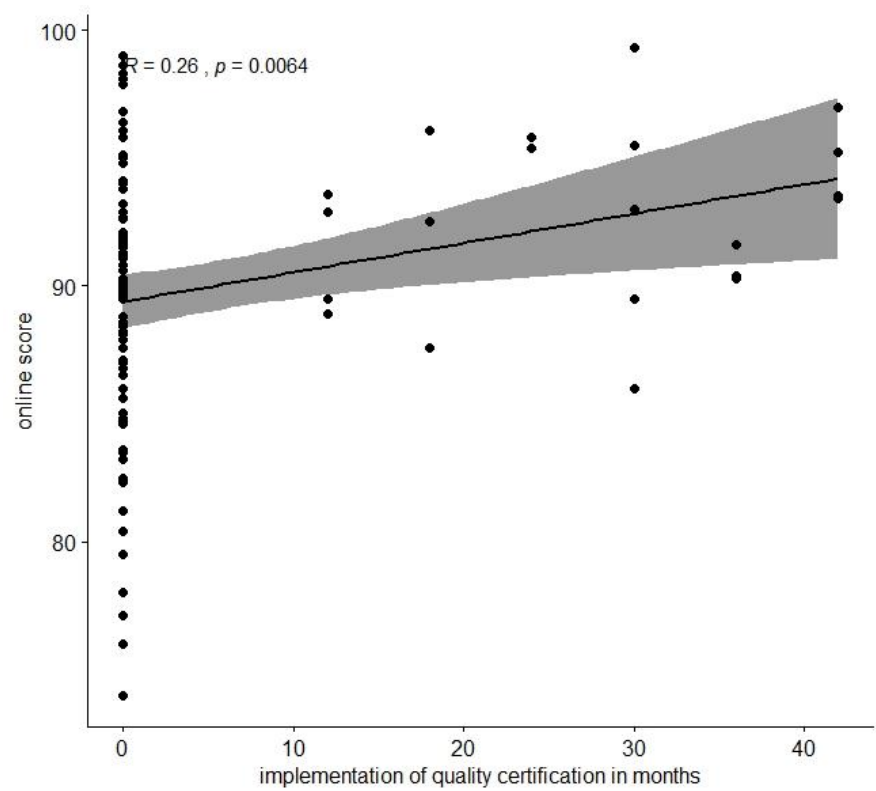

Source: The author

Although the earlier T-test assured that certified SMTEs have less reviews than noncertified SMTEs, the further linear regression analysis still demonstrates the positive effect of certification on the amount of online reviews (Figure 6). After SMTEs have been certified, there has been 1,9 increase monthly in the number of online reviews. The reference for this could be the quality management tools implemented in order to receive the certification. As stated previously in the theory part of this study, certified SMTEs are supposed to direct their customers to give feedback after the visit, preferably online. As online reviews and ratings are the main source of information for prospective new customers, their absence can reduce the competitive advantage of an SMTE. In addition, the analysis on the impact of social media on hotels performance conducted by Anderson (2012) confirmed, each new review a hotel adds increases its odds of being selected by 0.2 percent. 
ToSEE - Tourism in Southern and Eastern Europe, Vol. 5, pp. 739-756, 2019

T. Veideman: COMPARATIVE STUDY OF ONLINE CUSTOMER SATISFACTION BETWEEN ...

Figure 6: Summary statistics of linear regression model

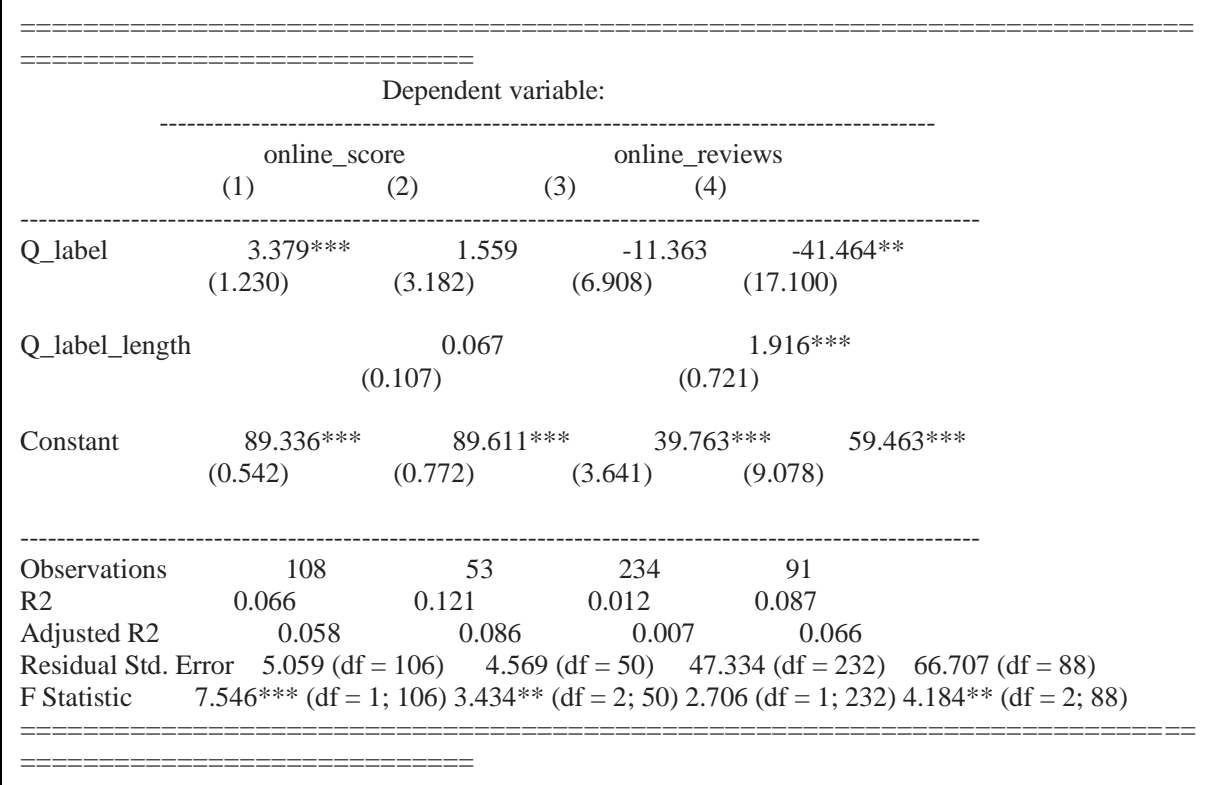

Note: $* \mathrm{p}<0.1 ; * * \mathrm{p}<0.05 ; * * * \mathrm{p}<0.01$

Source: The author

The regression model in Figure 7 displays that even though certified SMTEs with more reviews tend to have lower online score, their overall ratings are still relatively higher and more stable compared to non-certified SMTEs. Again, these findings comprehend with previous studies underlying the relevance of quality management on customer satisfaction. 


\section{Figure 7: Regression model}

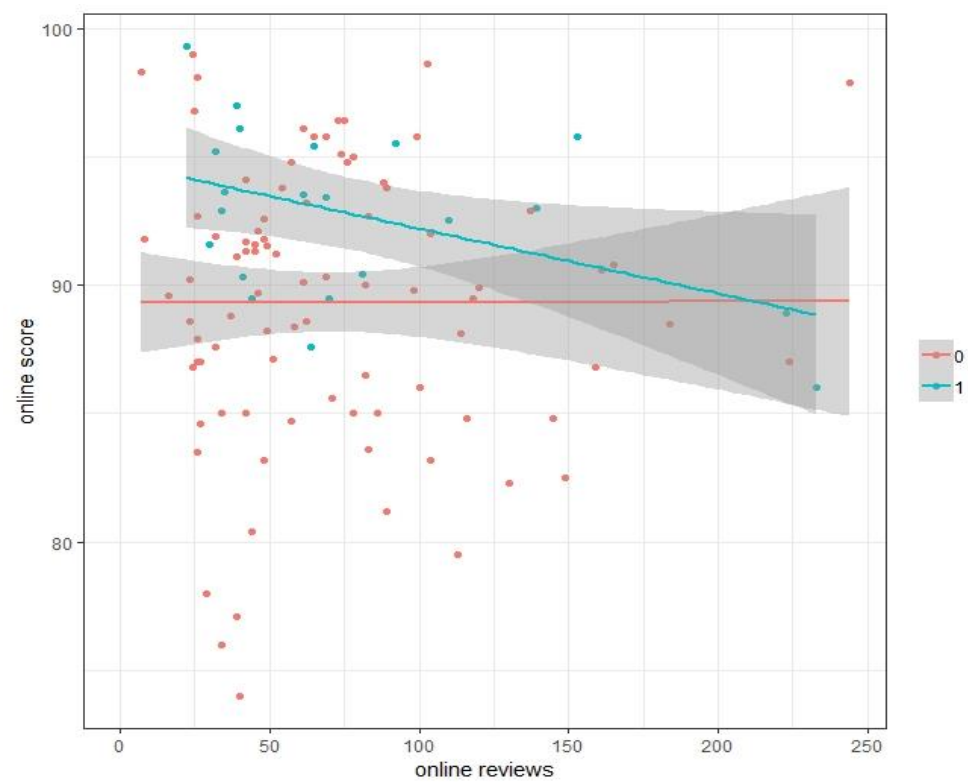

Source: The author

Considering the results of preceding analyses the author can evaluate both hypotheses. First, hypothesis 1 is rejected. The difference of means test does not indicate significant differences in the amount of online reviews between certified and non-certified SMTEs. There is also no statistically significant correlation between the number of reviews and scores given. However, the linear regression analysis on online reviews and the length of the period since the certification was acquired indicates monthly increase in the amount of online reviews. After acquiring the certification, SMTEs will receive 1,9 reviews more in every month. This verifies the positive effect of certification on the amount of online reviews.

Second, hypothesis 2 is accepted. The test of differences in mean shows that certified SMTEs have higher review scores than non-certified SMTEs. The implementation of quality certification will increase the chance of receiving higher online score by 3,4 points in GRI. In addition, the final step is to attach the verified hypothesis to Andersons (2012) model. His work estimates that a 1-percent increase in online reputation, as measured by ReviewPro's GRI, results in up to a 1.42-percent increase in RevPAR. Therefore, it can be confirmed that certified SMTEs with higher online scores are more likely to gain a competitive advantage over the ones without certification. 
ToSEE - Tourism in Southern and Eastern Europe, Vol. 5, pp. 739-756, 2019

T. Veideman: COMPARATIVE STUDY OF ONLINE CUSTOMER SATISFACTION BETWEEN ...

\section{CONCLUSION}

The aim of this study is to investigate the relationship between quality certification and online customer satisfaction. There is a growing demand for increased research in the area, as the majority of DMOs use quality certification to regulate the tourism market and raise the competitiveness of a destination. This study confirms that certified SMTEs perform better than non-certified SMTEs in terms of online customer satisfaction.

First, current study analyzed the amount of online reviews given to certified and noncertified SMTEs. The results of T-test revealed that certified SMTEs do not have statistically significantly more online reviews than non-certified SMTEs. One reasonable explanation to that could be the customers' habits to consume online and social media daily. This constant dependence steers everyone to share their experience online, regardless of whether they were purposefully directed to reveal it. Yet, further analysis verified the positive effect of certification on the amount of online reviews. After acquiring the certification, SMTEs will start to receive 1,9 reviews more in every month. This phenomenon might be a result of quality certification implementation, which criteria require SMTEs to collect and monitor feedback to enhance customer satisfaction.

Second, this study examined whether quality certified SMTEs receive higher online ratings than non-certified SMTEs. The statistical analysis carried out using a comparison of means, a correlation analysis, and a regression analysis, confirms that certified SMTEs have a statistically significant higher online ratings than non-certified SMTEs. Which allows to conclude that certified SMTEs perform better in terms of online customer satisfaction in comparison to non-certified SMTEs because their customers perceive better quality for the services provided.

The results of this study are in line with previous studies emphasizing the positive impact of quality management on customer satisfaction (Ooi et. al 2011, Piskar 2007, Mehra and Ranganathan 2008). According to this literature, quality management systems provide tools to enhance customer focus and achieve higher customer satisfaction. Due to the predominance of ITC driven business industry, those customers are increasingly sharing their experiences after their trip and searching opinions of others prior to their travel on various online platforms. Therefore, one can assume that customers visiting certified SMTEs are more likely to perceive the service they expected and communicate this experience online, which will result in higher online ratings.

The main contribution of this study is to verify the positive relationship between the implementation of quality certification and online customer satisfaction. The benefits of quality management on different aspects of business performance has been previously empirically studied concentrating on large hotels (Heras-Saizarbioria 2015, PereiraMoliner and Tari 2015, Dragicevic and Žaekovic 2013, Nield and Kozak 1999). Whereas current research has a different focus, investigating small and medium enterprises due to their predominance in the tourism sector. There are numerous quality certifications specifically tailored for SMTEs, as for example ISO certifications are claimed to be too difficult for SMTEs to follow. This study confirms that those specifically designed certifications are fulfilling their purpose and offer competitive advantage for SMTEs who implement them. 
ToSEE - Tourism in Southern and Eastern Europe, Vol. 5, pp. 739-756, 2019

T. Veideman: COMPARATIVE STUDY OF ONLINE CUSTOMER SATISFACTION BETWEEN ...

Limitations of the present study direct implications for future research. Although the sample sizes are adequate for the purpose of this study, future studies could use larger samples drawn from a wider variety of countries and certification schemes. Larger sample size decreases the standard error in the estimates and gives more precise approximation of the actual population mean. An analysis of such relationships within wider geographical contexts could provide further insights understanding the connection between quality management and online customer satisfaction. Next step would be a pilot study to test the proposed framework incorporating online reviews into quality certification. Furthermore, since online customer satisfaction is by far not the only factor influencing competitive advantage, future studies could investigate the relationship between quality certification and financial performance or other business outcomes. Future studies could also consider adopting longitudinal research design that could monitor the change in customer satisfaction taking into account the period that SMTE has been quality certified.

In conclusion, this paper contributes to the limited literature on understanding the relationship between quality management and online customer satisfaction in tourism sector, providing considerable insight for future studies in this field.

\section{REFERENCES}

Alonso-Almeida, M.M. and Rodriguez-Anton, J. and Rubio-Andrada, L. (2012), "Reasons for implementing certified quality systems and impact on performance: an analysis of the hotel industry", The Service Industries Journal, Vol. 32, No. 6, pp. 919-936. doi: 10.1080/02642069.2010.545886

Anderson, C. (2012), "The impact of social media on lodging performance", Cornell Hospitality Report, Vol. 12, No. 15 , pp. 6-11.

Anderson, C.K. and Blomberg-Nygard, A. (2016), "United Nation World Tourism Organization Study on online Guest Reviews and Hotel Classification Systems: An Integrated Approach”, Service Science, Vol. 8, No. 2, pp. 139-151. doi: 10.1287/serv.2016.0139

Augustyn. M.M. (1998), “The road to quality enhancement in tourism”, International Journal of Contemporary Hospitality Management, Vol. 10, No. 4, pp. 145- 158 https://doi.org/10.1108/09596119810222113

Buhalis, D. and Law R. (2008), "Progress in information technology and tourism management: 20 years on and 10 years after the Internet - The state of eTourism research", Tourism Management, Vol. 29, pp. 609-623. doi: 10.1016/j.tourman.2008.01.005

Butnaru, G.I. and Miller, A. (2012), "Conceptual approaches on quality and theory of tourism services", Procedia Economics and Finance, Vol. 3, pp. 375-380. doi: 10.1016/S2212-5671(12)00167-0

Browning, V. and Fung So, K.K. and Sparks, B. (2013), "The Influence of Online Reviews on Consumers' Attributions of Service Quality and Control for Service Standards in Hotels”, Journal of Travel \& Tourism Marketing, Vol. 30, No. 1-2, pp. 23-40. doi: https://doi.org/10.1080/10548408.2013.750971

Casadesus, M. and Marimon, F. And Alonso, M. (2010), "The future of standardised quality management in tourism: evidence from the Spanish tourist sector", The Service Industries Journal, Vol. 30, No. 14 pp. 2457-2474. doi: 10.1080/02642060802712822

Cochran, W.G. (1977), Sampling techniques, John Wiley \& Sons Inc, USA

Đukić, S. and Kijevčanin, V. (2012), "Service Quality and Determinant of Customer Satisfaction", Economics and Organization, Vol. 9, No. 3, pp. 311-325.

Dragičević, M. and Žarković, K. (2013), "Influence of Quality Management System ISO 9001 at hotel business practice in Croatia", Proceedings of the "Scientific Management" and Management Science Today International Scientific Conference.

Eklof, J.A. and Westlund, A. (1998), "Customer satisfaction index and its role in quality Management", Total Quality Management, Vol. 9, No. 4-5, pp. 80-85. doi: 10.1080/0954412988613

Fourie, L. (2015), "Customer satisfaction: a key to survival for SMEs?", Problems and Perspectives in Management, Vol. 13, No. 3-1, pp. 181-188. 
ToSEE - Tourism in Southern and Eastern Europe, Vol. 5, pp. 739-756, 2019

T. Veideman: COMPARATIVE STUDY OF ONLINE CUSTOMER SATISFACTION BETWEEN

Heras-Saizarbitoria, I. and Arana, G. and Boiral, O. (2015), "Do ISO 9001-certified hotels get a higher customer rating than non-certified ones?", International Journal of Hospitality Management, Vol. 51, pp. 138-146

Holjevac, A. (1996), "Total Quality Management for the Hotel Industry", Tourism Hospitality Management, Vol. 2, No. 1, .pp. 67-80.

Ishida, K. and Slevitch, L. and Siamionava, K. (2016), "The Effects of Traditional and Electronic Word-ofMouth on Destination Image: A Case of Vacation Tourists Visiting Branson, Missouri", Administrative Sciences, Vol. 6, No. 12, pp. 1-17.

Kobylanski, A. and Pawlowska, B. and Strychalska-Rudzewicz, A.(2011), "The Role of Ctsomer Staisfaction ine the Quality Management Systems: a Crosscultural Study", International Journal of Management and Marketing, Vol. 4, No. 3.

Komšić, J. and Dorčić, J. (2016), "Tourism Destination Competitiveness and Online Reputation: Conceptualization and literature framework analysis“, Tourism \& Hospitality Industry 2016, Congress Proceedings, pp. 144-157.

Lleshi, S. and Lani, L. (2017), "Effects of a Quality Management System on the Financial Performance in Banking Sector: Case Study Kosovo", European Journal of Multidisciplinary Studies, Vol. 67, No. 4, pp. 67-75. doi: 10.26417/ejms.v4i2

Lui, T-W. and Bartosiak, M. and Piccoli, G. and Sadhya, V. (2018), "Online review response strategy and its effects on competitive Performance", Tourism Management, Vol. 67, pp. 180-190. doi: https://doi.org/10.1016/j.tourman.2018.01.014

Mauri, A. and Minazzi, R. (2013), "Web Reviews Influence on Expectations and Purchasing Intentions of Hotel Potential Customers", International Journal of Hospitality Management, Vol. 34, pp. 99-107. doi: 10.1016/j.ijhm.2013.02.012

Mehra, S. and Ranganatha, S. (2008), "Implementing total quality management with a focus on enhancing customer satisfaction”, International Journal of Quality \& Reliability Management, Vol. 25, No. 9 pp. 913-927. https://doi.org/10.1108/02656710810908070

Namhyun, K. and Wicks, B.E. (2010), "Rethinking Tourism Cluster Development Models for Global Competitiveness", International CHRIE Conference-Refereed Track 28.

Nield, K. and Kozak, M. (1999), "Quality Certification in the Hospitality Industry: Analyzing the Benefits of ISO 9000“, Cornell Hotell and Restaurant Administration Quarterly, Vol. 40, No. 2, pp. 40-46. doi: https://doi.org/10.1177/001088049904000215

Niu, R.H. and Fan, Y. (2018), "An exploratory study of online review management in hospitality services", Journal of Service Theory and Practice, Vol. 28, No. 1, pp.79-98. https://doi.org/10.1108/JSTP-092016-0158

Ooi, K. and Lin, B. and Tan, B. and Chong, A.Y. (2011), “Are TQM practices supporting customer satisfaction and service quality?", Journal of Services Marketing, Vol. 25, No. 6, pp. 410-419. https://doi.org/10.1108/08876041111161005

Pereira-Moline, J. and Tari, J.J. (2015), "Quality certification, performance and size in hotel chains", Tourism Economics, Vol. 21, No. 2, pp. 307-324. doi: 10.5367/te.2013.0352

Phillips, P. and Zigan, K. and Santos, M.M. and Santos, S. and Schegg, R. (2015), "The interactive effects of online reviews on the determinants of Swiss hotel performance: A neural network analysis", Tourism Management, Vol. 50, pp. 130-141. https://doi.org/10.1016/j.tourman.2015.01.028

Piskar, F. (2007), "The Impact of the Quality Management System ISO 9000 on Customer Satisfaction of Slovenian Companies", Managing Global Transitions, Vol. 5, No. 1, pp. 45-61.

Pourfakhimi, S. (2014), "The Impact of Users'“Online Reviews" and "Ratings" on Consumers' Behaviour toward Hotel Selection Factors", Information and Communication Technologies in Tourism, pp. 104-114.

Reyner, A.P. and García, V.G. and Rodríguez, A.S. and Vivar, R.M. (2017). "Quality management and customer satisfaction in a tourist destination, a structural equation analysis", Polish Journal of Management Studies, Vol. 16, No. 1. pp. 175-186. doi: 10.17512/pjms.2017.16.1.15

Rodríguez-Díaz, M. and Rodríguez-Díaz, R. and Espino-Rodríguez, T.F. (2018), "Analysis of the Online Reputation Based on Customer Ratings of Lodgings in Tourism Destinations", Administrative Science, Vol. 8, No. 3, pp. 1-18. https://doi.org/10.3390/admsci8030051

Rodríguez-Díaz, M and Rodríguez-Voltes, C.I. and Rodríguez-Voltes, C. (2018), "Gap Analysis of the Online Reputation”, Sustainability, Vol. 10, No. 5, pp. 1-15. doi:10.3390/su10051603

Rstudio, Integrated development environment for R (Version 1.1.463) [Computer software]. Boston, MA Retrieved February 16, 2019. Available from http://www.rstudio.org/

Shahab, P. (2014), "The Impact of Users" "Online Reviews" and "Ratings" on Consumers' Behaviour toward Hotel Selection Factors", Information and Communication Technologies in Tourism, pp. 104-114. 
ToSEE - Tourism in Southern and Eastern Europe, Vol. 5, pp. 739-756, 2019

T. Veideman: COMPARATIVE STUDY OF ONLINE CUSTOMER SATISFACTION BETWEEN ...

Sparks, B.A. and Perkins, H.E. and Buckley, R. (2013), “Online travel reviews as persuasive communication The effects of content type, source, and certification logos on consumer behavior", Tourism Management, Vol. 39, pp. 1-9. doi: http://dx.doi.org/10.1016/j.tourman.2013.03.007

Zhou, L. and Ye, S. and Pearce, P.L. and Wu, M-Y. (2014), "Refreshing Hotel Satisfaction Studies by Reconfiguring Customer Review Data”, International Journal of Hospitality Management, Vol. 38, pp. 1-10.

Tepelus, C.M. and Cordoba, R.C. (2005). "Recognition schemes in tourism-from 'eco' to 'sustainability"?", Journal of Cleaner Production, Vol. 13, pp. 135-140.

Tari, J.J. and Heras-Saizarbitoria, I. and Dick, G. (2013), "Internal and external drivers for quality certification in the service industry: Do they have different impacts on success?", Service Business, Vol. 8, No. 2, pp. 337-354. doi:https://doi.org/10.1007/s11628-013-0198-6

Tepelus, C.M. and Cordoba, R.C. (2005), "Recognition schemes in tourism - from 'eco' to 'sustainability'?", Journal of Cleaner Production, Vol. 13, No. 2, pp. 135-140. doi: 10.1016/j.jclepro.2003.12.015

Vajčnerová, I. and Žiaran, P. and Ryglová, K. and Andráško, I. (2014), "Quality management of the tourist destination in the context of visitors' satisfaction", Procedia Economics and Finance, Vol. 12, pp 718-724.

Weckenmann, A. and Akkasoglu, G. and Werner, T. (2015), "Quality management - history and trends", The TQM Journal, Vol. 27, No. 3, pp. 281-293. https://doi.org/10.1108/TQM-11-2013-0125

World Tourism Organization UNWTO (2014), Online Guest Reviews and Hotel Classification Systems - An Integrated Approach, Madrid

Ye, Q. and Gu, B. and Chen, W. and Law, R. (2008), "Measuring the Value of Managerial Responses to Online Reviews - A Natural Experiment of Two Online Travel Agencies", ICIS 2008 Proceedings. http://aisel.aisnet.org/icis2008/115

Yoon, Y. And Uysal, M. (2005), "An examination of the effects of motivation and satisfaction on destination loyalty: a structural model”, Tourism Management, Vol. 26, pp. 45-56.

Triin Veideman, PhD Candidate

Estonian Business School

Department of Marketing and Communication

Lauteri 4, Tallinn, 10114, Estonia

Phone: +3725156604

E-mail: triin.veideman@gmail.com 